\title{
ANALISIS PENGARUH PERSEPSI KUALITAS PELAYANAN DAN PERCEIVED VALUE TERHADAP KEPUASAN RELIGIUS UNTUK MENINGKATKAN MINAT MENABUNG ULANG (Studi Pada BNI Syariah Semarang)
}

\author{
Hibba Al Kanzu*, Harry Soesanto ${ }^{1}$ \\ harrysoesantose@gmail.com \\ Jurusan Manajemen Fakultas Ekonomika dan Bisnis Universitas Diponegoro \\ Jl. Prof. Soedharto SH Tembalang, Semarang 50239, Phone: +622476486851
}

\begin{abstract}
The problem in this research is a decrease in the amount of third party funds (savings) are decreased and the high number of closing the savings account of Islamic banking. This research aims to test the power of perceived service quality and perceived value to religious satisfaction to improve consumer resaving interest in an Islamic Banking in semarang (study in BNI Syariah). This study using three independent variable is perceived service quality and perceived value, variable resaving intention consumer as a dependent variable and variable religious satisfaction as intervening.

A method of this research technique using probability sample that is random sampling and clusters of sampling to sample as many as 100 of respondents in the middle class and over who had bought an apartment in semarang. A method of data analyst using a technique double regression analysis, the analysis includes: test the validity of, a test of reliability, test the assumption of the classics, linear regression test doublet test, test $f$, test the coefficients determined and test sobel.

The results show significant and positive effect perceived service quality to religious satisfaction and resaving intention, significant and positive effect perceived value to religious satisfaction and repurchase intention, and then significant and positive effect religious satisfaction to repurchase intention.
\end{abstract}

Keywords : Perceived Service Quality, Perceived Value, Religious Satisfaction, Repurchase Intention.

\section{PENDAHULUAN}

Indonesia merupakan negara dengan penduduk terbesar ke empat di dunia. Indonesia menjadi negara dengan penduduk muslim terbanyak di dunia. Indonesia memiliki jumah penduduk muslim sebanyak 207.176.162 jiwa (data BPS 2010). Dengan persentase $87,18 \%$ penduduk indonesia beragama islam. Penduduk muslim di indonsia sangat taat dalam beribadah dibandingkan negara lain. Menurut survey dari Pew research center indonesia memiliki tingkat ketaatan yang tinggi dalam menjalankan rukun islam dibandingkan dengan negaranegara berpenduduk islam lainnya. Namun dengan jumlah penduduk yang sangat besar dan tingkat religiusitas yang tinggi. Menurut OJK Market share perbankan syariah di indonesia di bandingkan dengan perbankan konvensional hanya sebesar $5 \%$ per oktober 2014. Dengan jumlah nasabah 
dibawah 10 juta orang. Data OJK ini sangat kontras dengan jumlah penduduk muslim di Indonesia yang mencapai 200 juta jiwa. Hal menunjukkan perbakan syariah masih memiliki potensi untuk membesar market sharenya. Padahal menurut fatwa MUI no 1 tahun 2004 tentang bunga dan riba.

Disebutkan dengan jelas jika hukum praktek pembungaan adalah riba nasiah yang hukumnya haram. Oleh sebab itu bagi yang sudah ada di wilayahnya kantor Lembaga Keuangan Syariah dan mudah dijangkau maka tidak diperbolehkan melakukan transaksi dengan perhitungan bunga. Sedangkan bagi wilayah yang belum ada kantior/jaringan lembaga keuangan syariah diperbolehkan melakukan kegiatan transaksi di lembaga keuangan konvensional berdasarkan prinsisp dharurat/hajat. Dalam penjelasan tersebut dengan tegas MUI menyatakan jika menabung di lembaga keuangan konvensional merupakan tidakan yang di haramkan. Walaupun dengan niatan tidak mengambil bunga yang di berikan. Hal ini dikarenakan menabung di Lembaga keuangan konvensional sama halnya mereka membantu melakukan transakasi riba. Namun ada kemurahan untuk yang tidak terdapat lembaga keuangan syariah di wilayahnya.

Rendahnya market share perbankan syariah di indonesia dipengaruhi oleh terbatasnya sumber daya modal dan jaringan yang dimiliki perbankan syariah. Sehingga perbankan syariah tidak mampu menjangkau dan melayani konsumen potensial di berbagai wilayah di indonesia. Jaringan perbankan Syariah yang ada saat ini hanya terbatas di beberapa kota besar saja. Jika dibandingkan dengan perbankan konvensional yang sudah memiliki sumber daya modal yang kuat dan jaringan yang lebih jauh lebih luas. Sehingga sulit untuk perbankan syariah untuk bersaing langsung dengan perbankan konvensional pada umumnya terutama untuk mendapatkan market share yang tinggi. Hal ini diperburuk dengan kebanyakan bank syariah merupakan bisnis unit dari perbankan konvensional. Sehingga perkembangan perbankan syariah masih dipengaruhi kebijakan dari induk perusahaan.

Rendahnya pemahaman masyarakat tentang perbankan Syariah dikarenakan rendahnya pemahaman masyarakat terhadap konsep ekonomi islam. Tidak semua umat muslim memahami pentingnya ekonomi islam. Hal ini diperparah dengan kurangnya sosialisasi perbankan syariah tentang produk yang mereka tawarkan perbankan syariah. Kurangnya sosialisasi mengenai perbedaaan konsep dan layanan yang diberikan dibandingkan dengan perbankan konvensional. Sehingga masyarakat pada umumnya masih beranggapan bahwa sistem perbankan yang di jalankan oleh perbankan Syariah tidak jauh berbeda dengan sistem perbankan konvensional yang selama ini berjalan.

Namun dengan seiring meningkatnya kesadaran umat muslim di Indonsia perbankan syariah mengalami pertumbuhan yang cukup bagus, walaupun market sharenya masih rendah. Semenjak peraturan perundangundangan tentang perbankan syariah muncul. Menurut data OJK perkembangan pertumbuhan aset Perbankan syariah setiap setiap tahunnya menigkat dari 2010 meningkat 30\%, 2011 meningkat 50\%, 2012 meningkat $90 \%$. Pertumbuhan ini terlihat sangat menjanjikan meskipun market share yang dimilki masih relatif kecil dibandingkan dengan perbankan konvensional yang sudah ada.

Ketatnya persaingan dunia usaha telah memicu perusahaan untuk terus berusaha menciptakan kepuasan untuk setiap pelanggannya. Karena dengan terciptanya kepuasan pelanggan merupakan hal yang penting, karena dapat memberikan banyak manfaat 
untuk perusahaan. Salah satu manfaat dari kepuasan konsumen adalah meciptakan hubungan yang baik antara pelanggan dan perusahan sehingga menciptakan loyalitas dan pembelian ulang. Hal tersebut sangat diperlukan oleh perbankan Syariah agar dapat bertahan dalam mengahadapi persaingan dengan perbankan konvensional. Karena dalam perbankan syariah perusahaan dituntut untuk memberikan pelayan yang dapat memuaskan nasabah baik dari segi bisnis maupun religiusitas mereka. Karena nasabah perbankan Syariah tidak hanya mencari kepuasan dari segi finansial. Melainkan kepuasan dari segi emosional dan spiritual.

Kepuasan konsumen merupakan aset yang penting bagi perusahaan karena dapar digunakan sebagai indikator atas kualitas dan pendapatan perusahaan dimasa mendatang. Kepuasan pelanggan adalah tingkat perasaan konsumen setelah membandingkan antara apa yang dia terima dan harapannya (Umar, 2005:65). Seorang pelanggan, jika merasa puas dengan nilai yang diberikan oleh produk atau jasa, sangat besar kemungkinannya menjadi pelanggan dalam waktu yang lama. Menurut Philip Kotler dan Kevin Lane Keller yang dikutip dari buku Manajemen Pemasaran mengatakan bahwa Kepuasan Konsumen adalah perasaan senang atau kecewa seseorang yang muncul setelah membandingkan kinerja (hasil) produk yang dipikirkan terhadap kinerja yang diharapkan (2007:177).

Pelanggan yang puas terhadap kualitas layanan akan meningkatkan minat beli pelanggan dan membuat pelanggan melakukan pembelian ulang. Pelanggan yang puas disebut sebagai retained customers sedangkan pelanggan yang tidak puas disebut sebagai lost customers. Pelanggan yang puas memiliki peran yang penting bagi perusahaan dalam menghadapi persaingan bisnis yang ketat. Sehingga perusahaan harus berusaha untuk meningkatkan jumlah pelanggan yang puas.

Kepuasan pelanggan dapat diperoleh apabila kinerja yang diberikan perusahaan sesuai dengan harapan yang dimiliki pelanggan. Apabila kinerja yang diterima pelanggan dibawah harapan, maka pelanggan akan merasa kecewa bahkan mengeluh. Namun jika kinerja yang diterima pelanggan sesuai dengan harapan yang dimiliki, maka pelanggan akan merasa puas. Bahkan jika kinerjanya melebihi harapan, maka pelanggan akan merasa sangat puas.

Kepuasan pelanggan dapat diperoleh perusahaan apabila perusahaan dapat memberikan kinerja sesuai dengan harapan pelanggan. Harapan pelanggan terbentuk karena adanya suatu nilai tertentu. Dimana nilai tersebut akan digunakan untuk mengevaluasi dan memperhitungkan penawaran yang memberikan nilai tertinggi. Oleh karena itu agar perusahaan dapat memberikan kinerja yang memuaskan pelanggan. Perusahaan harus berusaha menyediakan nilai-nilai yang dimiliki pelanggan.

Penurunan jumlah dana pihak ke tiga BNI Syariah bertolak belakang dengan hasil laporan keuangan semester 1 tahun 2015 BNI Syariah secara umum yang menyatakan terdapat peningkatan jumlah dana pihak ketiga sebesar $38,13 \%$. Tren penurunan ini diperkuat dengan banyaknya jumlah penutupan rekening BNI Syariah oleh nasabah Semarang hal ini menunjukkan terdapat penurunan minat menabung konsumen BNI Syariah Semarang. Menurunnya minat menabung nasabah BNI Syariah Semarang bisa jadi merupakan bentuk ketidakpuasan nasabah terhadap layanan yang diberikan. Ketidakpuasan nasabah perbankan Syariah bisa disebabkan karena pelayanan dan nilai yang diberikan tidak sesuai dengan persepsi yang dimiliki oleh nasabah BNI Syariah Semarang. 
Fokus kegiatan pemasaran tidak lagi hanya ditujukan agar terjadi kegiatan pertukaran maupuun transaksi yang berlangsung sekali saja, namun sudah mengarah pada transaksi yang bisa terjadi secara berkesinambungan. Jika dahulu kegiatan pemasaran hanya berakhir setelang terjadinya transaksi jual beli sudah terlaksana, maka sekarang pemsaran mulai berorientasi agar hubungan dengan konsumen bisa tetap terjaga dengan baik. Agar perusahaan dapat mempunyai daya saing dan produktifitas yang terjaga dan terus berkembang. Dengan demikian sebenarnya pada masa ini sangat penting bagi perusahaan untuk memahami percived value dan persepsi kualitas pelayanan untuk menghasilkan religious satisfaction guna meningkatkan minat menabung ulang nasabah.

Kepuasan pelanggan dipengaruhi oleh persepsi pelangan atas produk yang digunakannya. Persepsi pelanggan terbentuk dari nilai-nilai yang mereka miliki. Pelanggan perbankan pada umumnya menganut nilai islami yang baik. Sehingga mereka benar-benar mengerti kebutuhan mereka. Oleh karena itu mereka lebih memilih menggunakan jasa perbankan syariah dibandingkan dengan menggunakan jasa perbankan konvensional

Kepuasan pelanggan juga dipengaruhi oleh persepsi pelanggan terhadap kualitas pelayanan yang akan diberikan perusahaan. Sehingga perusahaan harus dapat memberikan pelayanan yang baik. Agar sesuai dengan harapan pelanggan sehinga kepuasan pelanggan akan maksimal. Perusahaan harus bisa memberikan pelayanan yang sesuai dengan persepsi yang dimiliki oleh pelanggan bahkan lebih. Perbankan syariah pada dasarnya memberikan jasa yang hampir sama dengan perbankan konvensional pada umumnya. Yaitu berupa jasa penghimpun dana dan penyaluran dana. Namun karena dasar nilai nilai yang digunakan berbeda, maka bentuk dan proses pelayanannya pun memiliki perbedaan yang signifikan.

Persepsi kualitas pelayanan pelanggan terbentuk akibat dari penggunaan produk yang pernah digunakan. Padahal persepsi kualitas jasa pelanggan perbankan pada umumya terbiasa dengan pelayanan yang diberikan oleh perbankan konvensional. Sehingga persepsi pelanggan pada umumnya sudah terbentuk dari penggunaan jasa dari perbankan konvensional. Perbankan syariah harus bisa menyesuaikan diri agar kualitas pelayanan yang diberikan sebaik kualitas pelayanan yang sudah dimiliki perbnakan konvensional pada umunya. Walaupun pelayanan yang mereka berikan sedikit berbeda dengan perbankan konvensional pada umumnya. Perbankan syariah harus berusaha sebaik mungkin agar pelanggan yang sudah terbiasa terhadap pelayanan perbankan konvensional tertarik menggunakan jasa yang mereka tawarkan.

\section{KERANGKA TEORITIS DAN PERUMUSAN HIPOTESIS}

\section{Pengaruh Persepsi Kualitas Pelayanan Terhadap Religius Satisfaction}

Menurut penelitian Lien-Ti dan Yu-Ching (2001) kualitas pelayanan sangat penting untuk memberikan nilai tambah untuk menjaga konsumen. ekspektasi konsumen muncul dari kebutuhan atau keinginan terhadap pelayanan yang akan diterima dari penyedia layanan. Perusahaan harus dapat dapat mempertahankan dan menigkatkan konsumen untuk persaingan usahanya. Oleh karena itu perusahaan harus memberikan pelayanan yang dapat menghasilkan kepuasan bagi konsumennya. Kepuasan konsumen dapat tercapai apabila perusahaan bisa memberikan pelayanan yang sesuai dengan persepsi yang 
dimiliki oleh konsumen dalam menggunakan pelayanan yang diberikan. Semakin tinggi kualitas pelayanan yang diberikan maka kepuasan konsumen akan meningkat (Sutanto, 2008)

H1: Persepsi Kualitas Pelayanan berpengaruh positif terhadap Religius Satisfaction

\section{Pengaruh Percieved Value terhadap Religious Satisfaction}

Menurut penelitin Eid dan ElGohary (2014) percieved value memiliki pengaruh positif terhadap kepuasan konsumen muslim. Perceived value sebagai rujukan penilaian konsumen secara keseluruhan terhadap kegunaan suatu produk/jasa berdasarkan persepsi atas apa yang telah didapat. Nilai adalah ikatan yang kuat pada persepsi konsumen atas manfaat dari produk yang diterima. Sedangkan kepuasan konsumen merupakan tingkat perasaan seseorang setelah membandingkan kinerja atau hasil yang dirasakan dengan harapannya. Manfaat yang seimbang dengan nilai, akan mempengaruhi kepuasan pelanggan (Sutanto, 2008).

H2: Percieved Value memiliki pengaruh positif terhadap Religius Satisfaction.

\section{Pengaruh Persepsi Kualitas Pelayanan terhadap Minat Menabung Ulang}

Berdasarkan penelitian

Parasuraman, Zeithaml, dan Berry (1988) mengemukakan jika persepsi kualitas mempunyai pengaruh positif terhadap minat beli ulang konsumen. Persepsi kualitas yang dirasakan oleh pelanggan akan berpengaruh terhadap kesediaan konsumen untuk membeli sebuah produk (Puspitasari, 2006). Oleh karena itu semakin tinggi persepsi kualitas konsumen maka minat beli konsumen akan semakin tinggi. Dengan memperbaiki persepsi kualitas konsumen maka akan minat beli ulang pelanggan akan semakin baik.

H3: Persepsi Kualitas Pelayanan berpengaruh positif terhadap Minat Menabung Ulang
Pengaruh Percieved Value terhadap
Minat Menabung Ulang
Kusdiyah (2012) konsumen secara keseluruhan terhadap kegunaan suatu produk/jasa berdasarkan persepsi atas apa yang telah didapat. Persepsi pelanggan terhadap nilai juga akan mempengaruhi keputusan pembelian dari pelanggan. berdasarkan penelitian Johanna (2006) percieved value memiliki pengaruh positif terhadap minat beli ulang pelanggan. semakin baik persepsi pelanggan terhadap nilai yang diberikan perusahaan maka minat beli ulang pelanggan akan semakin baik.

H4: Percieved Value memiliki pengaruh positif terhadap Minat Menabung Ulang.

\section{Pengaruh Religious Satisfaction Terhadap Minat Menabung Ulang} Minat beli konsumen merupakan kegiatan-kegiatan individu yang secara langsung terlibat dalam mendapatkan dan menggunakan barang dan jasa termasuk di dalamnya proses pengambilan keputusan pada persiapan dan penentuan kegiatan-kegiatan tersebut (Swastha dan Handoko, 2000). Menurut Hendra Fure (2013) Minat beli berhubungan dengan perasaan dan emosi, bila seseorang merasa senang dan puas dalam membeli barang atau jasa maka hal itu akan memperkuat minat beli, ketidakpuasan biasanya menghilangkan minat. Minat beli yang ada dalam diri konsumen merupakan fenomena yang sangat penting dalam kegiatan pemasaran, minat beli merupakan suatu perilaku konsumen yang melandaskan suatu keputusan pembelian yang hendak dilakukan.

Menurut Kotler, Bowen \& Makens (1999) mengenai minat beli ulang : minat beli yang timbul setelah adanya proses evaluasi alternatif dan di dalam proses evaluasi, seseorang akan membuat suatu rangkaian pilihan mengenai produk yang hendak dibeli 
atas dasar merek maupun minat.Pelanggan yang berkomitmen memiliki keterikatan emosional terhadap merek atau perusahaan yang dituju. Pada umumnya pelanggan mengekspresikan komitmen mereka dengan kepercayaan dan kesukaan terhadap merek tersebut serta kepercayan terhadap perusahaannya. Konsumen yang berkomitmen tidak ingin mencari informasi tambahan saat membuat keputusan pembelian. Selain itu mereka tidak mudah untuk berpindah ke merek pesaing. Walaupun mereka membeli produk milik pesaing karena promosi, mereka akan kembali ke merek semula. Karena perpindahan sementara itu hanya bersifat memanfaaatkan keuntungan yang ditawarkan merek lain. Minat beli ulang merupakan bagian dari perilaku pembelian dimana konteks minat beli tersebut terdapat dalam konsep loyalitas (Söderlund dan Vilgon, 1999).

Berdasarkan penelitian Baihaqi (2006) mengemukakan bahwa kepuasan konsumen memiliki pengaruh positif terhadap minat beli konsumen. Semakin tinggi tingkat kepuasan konsumen, semakin tinggi juga minat beli konsumen untuk membeli ulang. Dengan kepuasan pelanggan atas pelayanan secara keseluruhan maka akan membuat pelanggan benar-benar merasa puas dan akan memunculkan keinginan untuk terus menjalin hubungan kemitraan (minat untuk membeli ulang) Puspitasari (2006).

H5: Religius Satisfaction mempunyai penaruh positif terhadap Minat Menabung Ulang.

\section{METODE PENELITIAN Variabel Penelitian}

Variabel independen dalam penelitian ini adalah Persepsi Kualitas Pelayanan Persepsi kualitas pelayanan adalah perbandingan dari pelayanan yang seharusnya perusahaan tawarkan (dari ekspektasi) dibandingkan dengan persepsi dari performa pealyanan yang disediakan perusahaan. Variabel persepsi kualitas pelayanan dapat di ukur dengan indikator-indikator. Yaitu : Tangibles, Reliability, Responsiveness, Asssurance, Empathy. Pervieved Value menururt Kotler \& Keller (2008) Nilai yang dipersepsikan pelanggan adalah selisih antara penilaian pelanggan prospektif atas semua manfaat dan biaya dari suatu penawaran terhadap alternatifnya. Variabel Perceived Value dapat diukur dengan menggunakan indikator-indikator, yaitu : Quality Value, Value of money, Emotional value, Social value, Islamic physical attributes, dan Islamic non-phisycal attributes.

Variabel intervening dari
penelitian ini adalah Religious satisfaction merupakan perbandingan kinerja dengan harapan yang di miliki yang di pengaruhi oleh tingkat penerimaan konsumen terhadap agamanya. Konsumen akan merasa puas apabila kinerja yang diberikan sesuai dengan nilai agama yang di miliki. Variabel Religious satisfaction dapat diukur dengan menggunakan indikator indikator, yaitu : kesesuaian harapan, persepsi kinerja, penilaian pelanggan Variabel dependen dari penelitian ini adalah Minat Menabung Ulang Konsumen, Minat beli ulang konsumen merupakan proses terjadi setelah konsumen mengambil keputusan pembelian. Setelah melakukan pembelian konsumen akan melakukan evaluasi terlebih dahulu terhadap produk atau jasa yang akan digunakan, berdasarkan sisi manfaat atas produk atau jasa tersebut sesuai dengan yang dibutuhkan dan diinginkan oleh konsumen. Apabila produk atau jasa memiliki manfaat sesuai dengan yang diinginkan konsumen maka akan menimbulkan loyalitas konsumen, sehingga munculah minat konsumen untuk membeli ulang. Variabel minat menabung ulang konsumen dapat diukur dengan menggunakan indikator - 
indikator, yaitu : Frekuensi menabung, komitmen pelanggan, dan rekomendasi positif.

\section{Sampel Penelitian}

Populasi menurut Sugiyono (2004,) adalah wilayah generalisasi yang terdiri atas : obyek/ subyek yang mempunyai kualitas dan karakteristik teretentu yang ditetapkan oleh peneliti untuk dipelajari kemudian ditarik kesimpulannya. Jadi populasi bukan hanya orang, tetapi juga obyek dan benda - benda alam yang lain. Populasi juga bukan sekedar jumlah yang ada pada obyek/subyek yang dipelajari, tetapi meliputi seluruh karakteristik/ sifat yang dimilik oleh subyek atau obyek itu. Populasi dalam penelitian ini adalah nasabah BNI Syariah di Semarang yang pernah menabung dengan frekuensi minimal tiga kali, sejak membuka rekening di Bank BNI Syariah Semarang. Dan sudah menjadi nasabah di BNI Syariah selama kurang dari dua tahun sampai dengan lebih dari lima tahun. Penulis memilih populasi berupa nasabah yang sudah memiliki tabungan mulai dari kurang dari dua tahun sampai dengan lebih dari lima tahun. Agar memperoleh hasil data yang luas sehingga dapat menjelaskan variabel yang sudah ditentukan. Selain itu dengan menggunakan data dari konsumen dengan lama menjadi nasabah diharapkan dapat mengetahui perkembangan dan perubahan yang terjadi BNI Syariah yang dirasakan oleh nasabah.

Sampel menurut Sugiyono (2004) adalah bagian dari jumlah dan karakteristik yang dimiliki oleh populasi tersebut. Untuk mengetahui berapa besarnya sampel yang digunakan dalam penelitian ini maka digunakan pedoman dari buku Imam Ghozali ( 2013) yang menyatakan bahwa dengan model estimasi menggunakan Maximum Likelihood (ML) minimum diperlukan sampel 100. Ketika sampel dinaikkan di atas nilai 100 , metode ML meningkat sensitivitasnya untuk mendeteksi perbedaan antar data. Begitu sampel menjadi besar ( diatas 400 sampai 500), maka metode ML menjadi sangat sensitive dan selalu menghasilkan perbedaan secara signifikan sehingga ukuran Goodness of fit menjadi jelek.Jadi dapat direkomendasikan bahwa ukuran sampel antar 100 sampai 200 harus digunakan untuk metode estimasi ML.

Sampel yang digunakan dalam penelitian ini adalah nasabah BNI Syariah di kota semarang yang pernah menabung minimal 3 kali dan sudah menjadi nasabah selama minimal kurang dari dua tahun sampai dengan lebih dari lima tahun. yang diambil secara acak dan menurut kelompok. Oleh sebab itu, teknik pengambilan sampel yang digunakan dalam penelitian ini menggunakan teknik probabilitas sampel dengan metode simple cluster sampling dan random sampling . Untuk menentukan besarnya sample jika populasinya tidak diketahui maka penelitian ini menggunakan rumus Slovin, sebagai berikut :

$$
\begin{aligned}
& n=\frac{Z^{2}}{4(m v e)^{2}} \\
& n=\frac{1,96^{2}}{4(0,1)^{2}} \\
& n-96,04 \text { dibulatkanı merijadi } 100
\end{aligned}
$$

Keterangan :

$\mathrm{n} \quad=$ Jumlah Sampel

$\mathrm{Z}=$ Tingkat distribusi norma pada tarif signifikan alpha 5\% $=1,96$

Moe $=$ Margin of error yaitu tingkat kesalahan maksimal pengambilan sampel yang masih dapat ditoleransi atau yang diinginkan sebesar $10 \%$ atau 0,1 . 
Berdasarkan perhitungan diatas maka jumlah sampel yang digunakan sebabnya 96 orang. Untuk mengantisipasi kuesioner yang tidak dapat digunakan atau diolah maka sampel yang akan digunakan sebanyak 100 responden yang berada pada kelas menengah hingga atas yang pernah menabung minimal 3 kali di BNI Syariah di Kota Semarang.

\section{Metode Analisis}

Analisis yang digunakan dalam penelitian ini adalah analisis regresi linier berganda. Analisi regresi linear berganda digunakan untuk mengetahui beberapa besar pengaruh variabel bebas dan terikat, yaitu : Persepsi Kualitas Pelayanan (X1), Perecived Value (X2), terhadap Minat Menabung Ulang (Y2) dan Religious Satisfaction sebagai Intervening ( Y1).

Sehingga, rumus matematik pada persamaan regresi linier berganda yang digunakan dalam penelitian ini :

$$
\begin{array}{ll}
\mathrm{Y}_{1} & =\mathrm{a}_{1}+\mathrm{b}_{1} \mathrm{X}_{1}+\mathrm{b}_{2} \mathrm{X}_{2}+\mathrm{e}_{1} \\
\mathrm{Y}_{2} & =\mathrm{a}_{2}+\mathrm{b}_{2} \mathrm{X}_{1}+\mathrm{b}_{2} \mathrm{X}_{2}+\mathrm{b}_{3} \mathrm{Y}_{1}+\mathrm{e}_{2} \\
\text { Keterangan : } & \\
\mathrm{Y}_{1} \quad=\text { Religious Stisfaction } \\
\mathrm{Y}_{2}=\text { Minat Beli Ulang Konsumen } \\
\mathrm{X}_{1}=\text { Persepsi Kualitas Pelayanan } \\
\mathrm{X}_{2}=\text { Perceived Value } \\
\mathrm{b}_{1}, \mathrm{~b}_{2,} \mathrm{~b}_{3}=\text { Koefisien regresi } \\
\mathrm{e} \quad=\text { Error }
\end{array}
$$

\section{HASIL PENELITIAN DAN PEMBAHASAN \\ Deskripsi Sampel}

Sampel yang digunakan dalam penelitian ini adalah nasabah BNI

\begin{tabular}{|c|c|c|c|}
\hline No. & $\begin{array}{c}\text { Karakteristik } \\
\text { Demografi }\end{array}$ & Kategori & $\begin{array}{c}\text { Frekuensi } \\
\text { (Orang) }\end{array}$ \\
\hline \multirow[t]{4}{*}{1.} & Usia & 1. $18-21$ tahun & 19 \\
\hline & & 2. $22-30$ tahun & 69 \\
\hline & & 3. $31-40$ tahun & 4 \\
\hline & & 4. $>40$ tahun & 8 \\
\hline \multirow[t]{2}{*}{2.} & Jenis Kelamin & 1. Perempuan & 48 \\
\hline & & 2. Laki-laki & 52 \\
\hline \multirow[t]{4}{*}{3.} & Pekerjaan & 1. Karyawan & 24 \\
\hline & & 2. Wiraswasta & 16 \\
\hline & & 3. Pelajar/mahasiswa & 51 \\
\hline & & 4. Lain-lain & 9 \\
\hline \multirow[t]{3}{*}{4.} & Pendapatan tiap bulan & 1. $<\operatorname{Rp} 2.000 .000$ & 55 \\
\hline & & 2. 5.000 .000 & 37 \\
\hline & & 3. Rp 5.000.001 - Rp 10.000.000 & 8 \\
\hline \multirow[t]{3}{*}{5.} & Pengeluaran tiap bulan & 1. $<\operatorname{Rp} 1.000 .000$ & 55 \\
\hline & & 2. $R p 1.000 .001-R p 2.500 .000$ & 37 \\
\hline & & 3. Rp 2.500.001 - Rp 5.000.000 & 8 \\
\hline \multirow[t]{3}{*}{6.} & Lama menjadi nasabah & 1. $<2$ Tahun & 46 \\
\hline & & 2. $2-5$ Tahun & 49 \\
\hline & & 3. $>5$ Tahun & 5 \\
\hline
\end{tabular}
Syariah di kota semarang yang pernah menabung minimal 3 kali dan sudah menjadi nasabah selama minimal kurang dari dua tahun sampai dengan lebih dari lima tahun. Diperoleh hasil sebagai berikut :

Tabel 1

Demografi Responden 


\section{Deskripsi Variabel Uji reabilitas}

Uji reliabilitas adalah alat untuk mengujur suatu kuesioner yang merupakan indikator dari variabel atau konstruk.Suatu kuesioner akan dikatakan reliable atau handal apabila jawaban seseorang terhadap pertanyaan adalah konsisten atau stabil dari waktu ke waktu. Untuk mengukur kehandalan suatu variabel atau konstruk menggunakan uji statistikCronbach Alpha $(\alpha)$. Batas kehandalan suatu konstruk adalah apabila nilai Cronbach Alpha> 0,60 (Ghozali, 2011). Berikut hasil uji reliabilitas pada penelitian ini :

Tabel 2

Hasil uji reabilitas

\begin{tabular}{llll}
\hline No. & \multicolumn{1}{c}{ Variabel } & Cronbach Alpha & Standar Reliabilitas \\
\hline 1. & Persepsi Kualitas Pelayanan & 0,794 & 0,60 \\
2. & Perceived Value & 0,831 & 0,60 \\
3. & Religious Satisfaction & 0,701 & 0,60 \\
4. & Minat Menabung Ulang Konsumen & 0,666 & 0,60 \\
\hline
\end{tabular}

\begin{tabular}{lllc}
\hline No. & \multicolumn{1}{c}{ Variabel } & Cronbach Alpha & Standar Reliabilitas \\
\hline 1. & Persepsi Kualitas Pelayanan & 0,794 & 0,60 \\
2. & Perceived Value & 0,831 & 0,60 \\
3. & Religious Satisfaction & 0,701 & 0,60 \\
4. & Minat Menabung Ulang Konsumen & 0,666 & 0,60 \\
\hline
\end{tabular}

Berdasarkan hasil uji reliabilitas yang dijelaskan pada Tabel 4.16 menunjukkan bahwa nilai Cronbach Alpha dari masing-masing variabel diatas 0,60 , sehingga dapat disimpulkan bahwa indikator variabel Persepsi Kualitas Pelayanan, Perceived Value, Religious Saatisfaction dan Minat Menabung Ulang Konsumen semua reliabel dan dapat dipercaya atau handal untuk digunakan sebagai alat ukur variabel.

\section{Uji Validitas}

Uji validitas digunakan untuk mengukur sah atau valid tidaknya suatu kuesioner. Suatu kuesioner dikatakan valid apabila pertanyaan pada kuesioner mampu untuk mengungkapkan sesuatu yang akan diukur oleh kuesioner tersebut. Uji validitas dilakukan dengan membandingkan nilai $r$ hitung dengan $r$ tabel untuk degree of freedom $(\mathrm{df})=\mathrm{n}-$ 2 (Ghozali, 2011). Dalam hal ini $n$ adalah jumlah sampel, dalam penelitian ini jumlah sampel yang digunakan adalah sebanyak 100 orang, sehingga diperoleh $\mathrm{df}=100-2=98$ dengan tingkat signifikansi alpha 5\% $(0,05)$. Maka, diperoleh $\mathrm{r}$ tabel two tailed ( 2 sisi ) sebesar 0,1966. Jika $r$ hitung $>r$ tabel dan bernilai positif maka butir atau pertanyaan atau indikator tersebut dinyatakan valid, begitu juga sebaliknya jika $r$ hitung < $r$ tabel dinyatakan tidak valid (Ghozali, 2011). Berikut merupakan hasil dari uji validitas dalam penelitian ini : 
Tabel 3

Hasil uji validitas

\begin{tabular}{|c|c|c|c|c|c|}
\hline No. & Variabel Indikator & r hitung & $r$ tabel & Sig. & Keterangan \\
\hline 1. & $\begin{array}{c}\text { Persepsi Kualitas Pelayanan } \\
\text { - Indikator x1a } \\
\text { - } \quad \text { Indikator x1b } \\
\text { - Indikator x1c } \\
\text { - Indikator x1d } \\
\text { - } \quad \text { Indikator x1e }\end{array}$ & $\begin{array}{l}0,784 \\
0,760 \\
0,680 \\
0,768 \\
0,717\end{array}$ & $\begin{array}{l}0,1966 \\
0,1966 \\
0,1966 \\
0,1966 \\
0,1966\end{array}$ & $\begin{array}{l}0,000 \\
0,000 \\
0,000 \\
0,000 \\
0,000\end{array}$ & $\begin{array}{l}\text { Valid } \\
\text { Valid } \\
\text { Valid } \\
\text { Valid } \\
\text { Valid }\end{array}$ \\
\hline 2. & $\begin{array}{cl}\text { Perceived Value } \\
\text { - } & \text { Indikator x2a } \\
\text { - } & \text { Indikator x2b } \\
\text { - } & \text { Indikator x2c } \\
\text { - } & \text { Indikator x2d } \\
\text { - } & \text { Indikator x2e } \\
\text { - } & \text { Indikator x2f }\end{array}$ & $\begin{array}{l}0,810 \\
0,806 \\
0,861 \\
0,777 \\
0,648 \\
0,483\end{array}$ & $\begin{array}{l}0,1966 \\
0,1966 \\
0,1966 \\
0,1966 \\
0,1966 \\
0,1966\end{array}$ & $\begin{array}{l}0,000 \\
0,000 \\
0,000 \\
0,000 \\
0,000 \\
0,000\end{array}$ & $\begin{array}{l}\text { Valid } \\
\text { Valid } \\
\text { Valid } \\
\text { Valid } \\
\text { Valid } \\
\text { Valid }\end{array}$ \\
\hline 3. & $\begin{array}{rr}\text { Religious Satisfaction } \\
-\quad \text { Indikator y1a } \\
\text { - } \quad \text { Indikator y1b } \\
\text { - Indikator y1c }\end{array}$ & $\begin{array}{l}0,803 \\
0,811 \\
0,761\end{array}$ & $\begin{array}{l}0,1966 \\
0,1966 \\
0,1966\end{array}$ & $\begin{array}{l}0,000 \\
0,000 \\
0,000\end{array}$ & $\begin{array}{l}\text { Valid } \\
\text { Valid } \\
\text { Valid }\end{array}$ \\
\hline 4. & $\begin{array}{l}\text { Minat Menabung Ulang } \\
\text { Konsumen } \\
\text { - Indikator y2a } \\
\text { - Indikator y2b } \\
\text { - Indikator y2c }\end{array}$ & $\begin{array}{l}0,828 \\
0,769 \\
0,726\end{array}$ & $\begin{array}{l}0,1966 \\
0,1966 \\
0,1966\end{array}$ & $\begin{array}{l}0,000 \\
0,000 \\
0,000\end{array}$ & $\begin{array}{l}\text { Valid } \\
\text { Valid } \\
\text { Valid }\end{array}$ \\
\hline
\end{tabular}

Pembahasan Hasil Penelitian

Hipotesis pertama menunjukkan adanya pengaruh positif dan signifikan dari variabel persepsi kualitas pelayanan terhadap Religious Satisfaction. Hasil pengujian kedua variabel tersebut menunjukkan bahwa koefisien regresi dari pengaruh persepsi kualitas pelayanan terhadap religious satisfaction adalah sebesar 0,514 dan bernilai positif. Tingkat signifikansinya sebesar 0,000 dimana nilai signifikansi tersebut $<\alpha(0,05)$, sehingga persepsi kualitas pelayanan memiliki pengaruh yang positif dan signifikan terhadap religious satisfaction. Hasil ini memperkuat penelitian dari Lien-Ti dan Yu-Ching (2001) dimana persepsi kualitas pelayanan memiliki pengaruh sebesar 0,22 bernilai positif terhadap kepuasan konsumen perusahaan jasa.

Hipotesis kedua menunjukkan adanya pengaruh positif dan signifikan dari variabel perceived value terhadap Religious satisfaction. Hasil pengujian kedua variabel tersebut menunjukkan bahwa koefisien regresi dari pengaruh perceived value terhadap Religious satisfaction adalah sebesar 0,236 dan bernilai positif. Tingkat signifikansinya sebesar 0,000 dimana nilai signifikansi tersebut $<\alpha(0,05)$, sehingga perceived value memiliki pengaruh yang positif dan signifikan terhadap Religious satisfaction. Hasil ini memperkuat hasil penelitian dari Riyad Eid dan Hatem ElGohary (2014) dimana quality value memiliki pengaruh sebesar 0,221 dan bernilai positif terhadap kepuasaan konsumen, value for money memiliki pengaruh sebesar 0,16 dan bernilai positif terhadap kepuasaankonsumen, emotional value memiliki pengaruh sebesar 0,107 dan bernilai positif terhadap kepuasaan konsumen, social value memiliki pengaruh positif sebesar 0,15 dan signifikan terhadap kepuasaan konsumen. Islamic Physical Attributes memiliki pengaruh posistif sebesar 0,397 dan signifikan terhadap kepuasan 
konsumen, dan Islamic Non-Physical Attributes memiliki pengaruh positif sebesar 0,047 dan tidak signifikan terhadap kepuasan konsumen.

Gambar 1

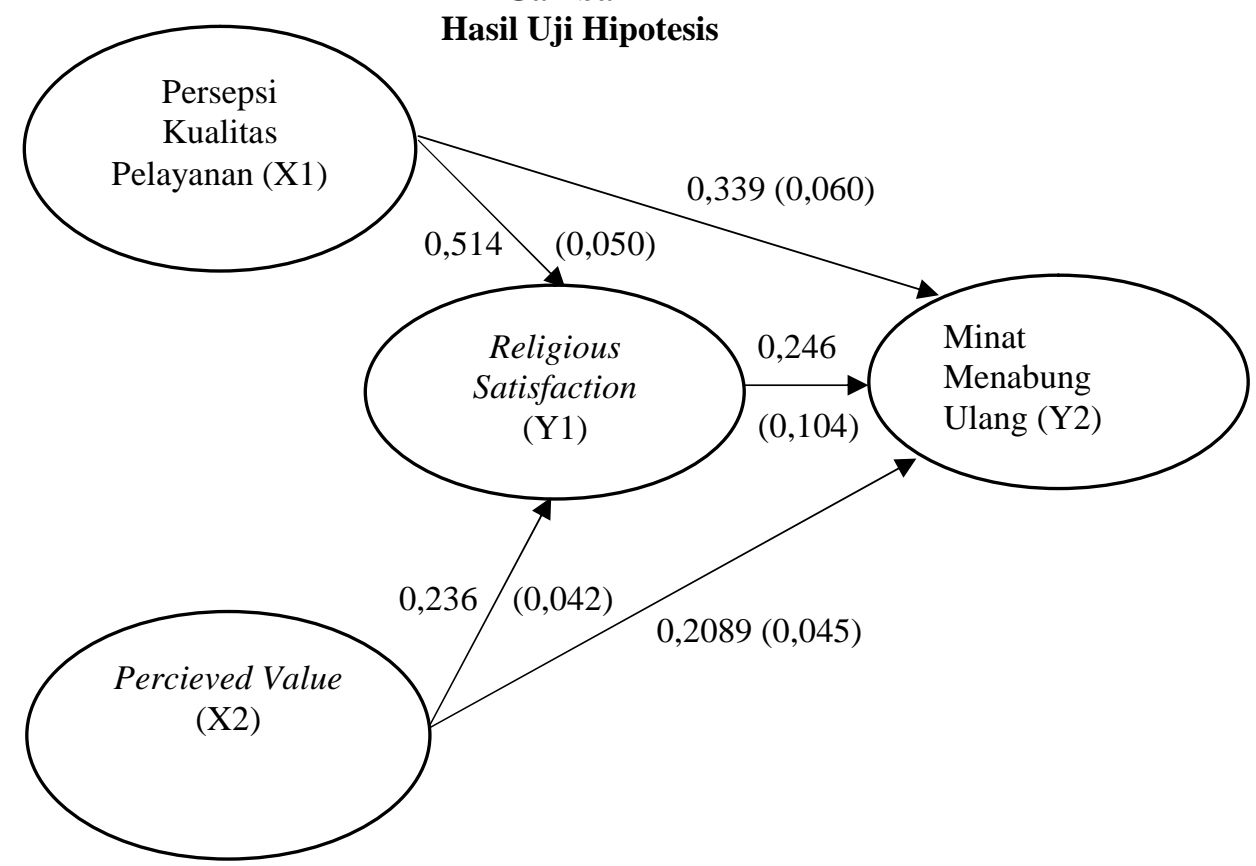

Hipotesis ketiga menunjukkan adanya pengaruh positif dan signifikan dari variabel persepsi kualitas pelayanan terhadap minat menabung ulang nasabah. Hasil pengujian kedua variabel tersebut menunjukkan bahwa koefisien regresi dari pengaruh persepsi kualitas pelayanan terhadap minat beli konsumen adalah sebesar 0,339 dan bernilai positif. Tingkat signifikansinya sebesar 0,001 dimana nilai signifikansi tersebut $<\alpha(0,05)$, sehingga persepsi kualitas pelayanan memiliki pengaruh yang positif dan signifikan terhadap minat menabung ulang nasabah. Hasil ini memperkuat penelitian dari Diana Puspitasari (2006) yang menyatakan bahwa persepsi kualitas pelayana memiliki pengaruh positif dan signifikan terhadap minat menabung ulang nasabah.

Hipotesis keempat menunjukkan adanya pengaruh positif dan signifikan dari variabel perceived value terhadap minat menabung ulang nasabah. Hasil pengujian kedua variabel tersebut menunjukkan bahwa koefisien regresi dari pengaruh perceived value terhadap minat beli ulang konsumen adalah sebesar 0,208 dan bernilai positif. Tingkat signifikansinya sebesar 0,021 dimana nilai signifikansi tersebut $<\alpha$ $(0,05)$, sehingga perceived value memiliki pengaruh yang positif dan signifikan terhadap minat menabung ulang nasabah. Hasil ini memperkuat hasil penelitian dari Myra Johanna $\mathrm{P}$ (2006) dimana perceived price value memiliki pengaruh sebesar 0,50 dan bernilai positif terhadap minat beli ulang konsumen.

Hipotesis kelima menunjukkan adanya pengaruh positif dan signifikan dari variabel religious satisfaction terhadap minat menabung ulang nasabah. Hasil pengujian kedua variabel tersebut menunjukkan bahwa koefisien regresi dari pengaruh religious satisfaction terhadap minat menabung ulang nasabah adalah sebesar 0,246 dan bernilai positif. Tingkat signifikansinya sebesar 0,017 dimana nilai signifikansi tersebut $<\alpha(0,05)$, sehingga religious satisfaction memiliki pengaruh yang 
positif dan signifikan terhadap minat menabung ulang nasabah. Hasil ini memperkuat penelitian dari Diana Puspitasari (2006) dimana kepuasan memiliki pengaruh yang positif sebesar 0,35 dan signifikan terhadap minat menabung ulang nasabah.

\section{KESIMPULAN}

Setelah dilakukan analisis dari hasil yang diperoleh dari penelitian ini maka dapat disimpulkan bahwa. Tingkat persepsi kualitas pelayanan nasabah terhadap BNI Syariah dapat meningkatkan kepuasan religious nasabah BNI Syariah Semarang dengan memberikan ketanggapan pelayanan yang baik (cepat dalam merespon keluhan nasabah, memahami keinginan nasabah dengan baik), memberikan jaminan pelayanan yang baik (memberikan jaminan keamanan tabungan, jaminan kehalalan menabung, pelayanan yang menyenangkan, dan tabungan dijamin oleh LPS), memberikan empati pelayanan yang baik (Petugas bersikap ramah, sopan, dan menyenangkan, berpakain rapi, dan murah senyum), memberikan kehandalan yang baik (tabungan tanpa potongan biaya, kemudahan melakukan transaksi, keamanan dalam menabunga. Melayani pembayaran zakat, dan melayani pembayaran kuliah), memberikan fasilitas yang baik (menyediakan ATM yang banyak, menyediakan ruang tunggu yang nyaman, dan mobile banking yang baik).

Tingkat percieved value yang baik akan meningkatkan religious satisfaction nasabah BNI Syariah Semarang. Dengan memberikan layanan yang sebanding dengan harga, biaya adaministrasi yang sesuai dengan kualitas layanan yang diberikan, mempengaruhi emosi nasabah, mencerminkan konsep diri dalam ingkungan sosial, memiliki atribut fisik islami yang baik (petugas berpakaina sesuai dengan syariat) dan memiliki atribut islami non-fisik (selalu mengucapkan salam) .

Persepsi kualitas pelayanan konsumen dapat meningkatkan minat menabung ulang nasabah di BNI Syariah Semarang. Nasabah yang memiliki persepsi kualitas yang baik akan terus menabung di BNI Syariah Semarng. Dengan menabung di BNI Syariah Semarang nasabah merasakan tabungannya bebas dari riba dan halal. Namun persepsi kualitas akan memiliki pengaruh yang lebih besar terhadap minat menabung ulang konsumen jika religius satisfaction nasabah terhadap BNI Syariah Semarang baik.

Perceived value konsumen dapat mengingkatkan minat menabung ulang nasabah di BNI Syariah Semarang. Nasabah yang mempunyai tingkat perceived value yang baik akan terus menabung di BNI Syariah Semarang. Dengan menabung di BNI Syariah Semarang nasabah meresa tabungan mereka di kelola dengan baik sesuai dengan konsep syariat islam. Namun perceived value akan memiliki pengaruh yang lebih besar terhadap minat menabung ulang konsumen apabila religious satisfaction. Religious satisfaction dapat meningkatkan minat menabung ulang konsumen di BNI Syariah Semarang. Semakin baik religious satisfaction maka konsumen akan kembali menabung di BNI Syariah Semarang. BNI Syariah Semarang memberikan pelayanan yang baik. Memberikan pengelolaan yang sesuai dengan syariat islam.

Dalam penelitiani ini tentunya masih ada keterbatasan-keterbatasan yang timbul. Keterbatasan yang di alami oleh peneliti adalah sebagai berikut. Pertama penelitian ini sulit dalam menyebarkan kuesioner, dikarenakan tidak tidak banyak nasabah yang kami temui bersedia mengisi kuesioner yang kami berikan. serta peneliti memiliki keterbatasan waktu hanya 1 bulan untuk menyebarkan kuesioner kepada 
responden, oleh sebab itu peneliti mengalami kendala dalam mengambil data responden. Kedua hasil pertanyaan terbuka dalam kuesioner kurang memberikan jawaban yang maksimal, sebab beberapa pertanyaan terbuka tidak diisi oleh reponden. Ketiga dalam penelitian ini menganalisis dari sisi produk jasa berupa tabungan. Sehingga penelitian ini masih belum bisa menggambarkan mengenai kinerja produk perbankan Syariah secara menyeluruh. Keempat hanya dua variabel independen yang digunakan dalam penelitian ini, sehingga hasil yang didapatkan kurang maksimal.
Keterbatasan yang ditemukan dalam penelitian kali ini dapat dijadikan sumber ide bagi penelitian yang akan datang. Berikut beberapa saran dari peneliti untuk penelitian yang akan dating. Pertama untuk penelitian selanjutnya diharapkan mampu menambahkan variabel lain yang dapat mempengaruhi minat beli konsumen terhadap BNI Syariah Semarang. Kedua penelitian yang akan datang juga diharapkan dapat memperluas lingkup penelitian yaitu dengan membandingkan persepsi konsumen terhadap pelayanan yang diberikan oleh perbankan syariah.

\section{REFERENSI}

Baihaqi, Yuzza. 2006. Tesis Analisis Pengaruh Kualitas Layanan Dan Keunggulan Produk Terhadap Kepuasan Pelanggan Dan Dampaknya Pada Minat Membeli Ulang. Universitas Diponegoro

Casas, F., Gonzalez, M., Figuer, C. and Malo, S. 2009. "Satisfaction with spirituality, satisfaction with religion and personal well being among Spanish adolescents and young universitas students". Applied Research Quality Life. Vol. 4. No. 1. pp. 2345.

Eid, Riyad dan El-Gohary, Hatem. 2014. The Role Of Islamic Religiosity $N$ The Relationship Between Perceived Value And Tourist Satisfaction. Tourism Management 46, 477-488.

Ferdinand, Augusty T. 2003. "Sustainable Competitive Advantage: Sebuah Eksplorasi Model Konseptual". Research Paper Seri Penelitian Manajemen, No.02/Mark/2003

Ferdinand, Augusty T. 2006. Metode Penelitian Manajemen: Pedoman Penelitian untuk Penulisan Skripsi, Tesis, dan Disertasi Ilmu Manajemen. Semarang: Badan Penerbit Universitas Diponegoo.

Ghozali, Imam. 2011. Aplikasi Analisis Multivariate dengan Program IBM SPSS 19. Semarang: Universitas Diponegoro.Kotler, Philip dan Amstrong. 2001. Prinsip - Prinsip Manajemen Pemasaran. Jakarta: Erlangga.

Fure, Hendra. 2013. Lokasi Keberagaman Produk, Harga, dan Kualitas PelayananPengaruhnya Terhadap Minat Beli Pada Pasar Tradisional. Jurnal EMBA.Vol.1. NO.3. Hal 273 - 278.Ghozali, Imam. 2005. SPSS dan Lisrel. Semarang: Universitas Diponegoro

Ghozali, Imam. 2006. SPSS dan Lisrel. Semarang: Universitas Diponegoro

Hasanudin Amin Abdul-Rahim Abdul-Rahman Dzuljastri Abdul Razak. 2014. "Theory of Islamic Consumer Behaviour”. Journal Islamic Marketing Vol 5 lss 2 pp. 273 301

Johanna, P Myra. 2006. Tesis Analisis Faktor-Faktor Yang Mempengaruhi Minat Beli Ulang. Universitas Diponegoro

Khasanah, Wiwin. 2015. Pengaruh Persepsi Mahasiswa UIN Sunan Kalijaga Tentang Perbankan Syariah Terhadap Minat Menabung Di Bank Syariah Mandiri. UIN Sunan Kalijaga 
Kusdyah, Ike. 2012. Persepsi Harga, Persepsi Merek, Persepsi Nilai, Dan Keinginan Pembelian Ulang Jasa Clinic Kesehatan. Jurnal Manajemen Pemasaran,Vol. 7 No. 1.

Kotler, Philip dan Keller, Kevin Lane. 2008. Manajemen Pemasaran Jilid 1. Jakarta: Erlangga.

Kotler, Philip. 2009. Manajemen Pemasaran Jilid 2. Jakarta: Erlangga

Bei, Lien-Ti dan Chiao, Yu-Ching. 2001. An Integrated Model For The Effect Of Percieved Product, Percieved Service Quality, And Percieved Price Fairness On Consumer Satisfaction And Loyalty. Journal of Consumer Satisfaction, Dissatisfaction and Complaining Behaviour.

Martono, Nanang.2011. Metode Penelitian Kuantitatif (Analisis isi dan Analisis Data Sekunder). Jakarta: Grafindo.

Mowen, Joh C dan Minor, Micahel. 2002. Perilaku Konsumen. Jakarta: Erlangga

Parasuraman, A., Valarie, A. Zithaml amd Leonard L. Berry, (1988), "SERVQUAL : A Multiple-Item Scale for Marketing Consumer Perceptions of Service", Journal of Retailing, 64 (Spring), 12-40.

Peter, Paul J dan C Oslon, Jerry. 1999. Perilaku Konsumen dan Strategi Pemasaran. Jakarta: Erlangga

Puspitasari, Diana. 2006. Tesis Analisis Penaruh Persepsi Kualitas Dan Kepuasan Pelanggan Terhadap Minat Beli Ulang. Universitas Diponegoro

Sugiyono.2001. Metode Penelitian Administrasi. Bandung: Alfabeta.

Sutanto, Jeanne Ananti. 2008. Pengaruh Service Quality Dan Perceived Value Terhadap Kepuasan Dan Loyalitas Konsumen Apartemen di Kota Surabaya. Majalah Ekonomi. Tahun XVII.

Sunarto. 2006. Perilaku Konsumen. Yogyakarta: Penerbit AMUS

Setiadi, Nugroho. 2003. Perilaku Konsumen. Jakarta: Prenada Media.

Söderlund, Magnus dan Mats Vilgon 1999. :customer satisfaction and links to customer profitability : an empirical examination of the association between attitudes and behaviour", working paperseries in business administration, No. 1.

Swastha, Basu dan Handoko, Hani. 2000. Manajemen Pemasaran: Analisis Perilaku Konsumen. Yogyakarta: BPFE

Tiliouine, H. (2009), "Measuring satisfaction with religiosity and its contribution to the personal well being index in a muslim sample", Applied Research Quality Life, Vol. 4 No. 1, pp. 91-108.

http://www.ojk.go.id/

http://www.bi.go.id/

Zeithaml, Valarie A. and Mary J. Bitner 1996. Service Marketing, I Ed. New York: McGraw-Hill. 